\title{
Rhizoremediation: A Promising Rhizosphere Technology
}

\author{
Dr. S. Kala, \\ Assistant professor, Department of Botany, Seethalakshmi Ramaswami College, Trichirappalli-2
}

\begin{abstract}
Interactions between microorganisms and plants have undoubtedly had major effects on the development of civilization since humans began to rely extensively on cultivated crops for food. Positive and negative interactions take place not only between microbes but also between microbes and plants. The rhizosphere is a zone of predominantly commensal and mutualistic interactions between plants and microbes. Rhizospheric microbes can degrade the majority of environmental pollutants and degradation process stops when the microbe is deprived of food. These microbes have access to the best food source available in soil, namely root exudates. Microbial degradation of contaminants in the rhizosphere provides a positive effect for the plant; the pollutant concentration is decreased in the area near the roots and the plant can grow better than those in contaminated areas. Worldwide, contamination of soil and ground water is a severe problem. The negative effects of pollutants on the environment and on human health are diverse and depend on the nature of the pollution. Awareness about harms of pollution in the scientific world has aroused in 1990s but now even general public is highly concerned about this issue. The search for alternative methods for excavation and incineration to clean polluted sites resulted in the application of bioremediation techniques. A cost effective and highly ethical method Rhizoremediation which involves the breakdown of contaminants in soil resulting from microbial activity that is enhanced in rhizosphere. So, an effort is made to review the recent advancements on rhizoremediation-based abolition of heavy metals.
\end{abstract}

Key words: rhizosphere; rhizoremediation; heavy metals.

\section{Introduction}

Intensification of agriculture and manufacturing industries has resulted in increased release of a wide range of xenobiotic compounds to the environment. Excess loading of hazardous waste has led to scarcity of clean water and disturbances of soil thus limiting crop production (Kamaludeen et al., 2003). The negative effects of pollutants on the environment and on human health are diverse and depend on the nature of the pollution. Common contaminants include petroleum hydrocarbons (PHCs), polycyclic aromatic hydrocarbons (PAHs), halogenated hydrocarbons, pesticides, solvents, metals, salt and the results in stresses on human and ecosystem health. The search for alternative methods for excavation and incineration to clean polluted sites resulted in the application of rhizoremediation techniques. Rhizosphere bioremediation or rhizodegradation is the enhanced biodegradation of recalcitrant organic pollutants by root-associated bacteria and fungi under the influence of selected plant species. Use of selected vegetation and sound plant management practices, increase the total proportion of pollutant degraders in numbers and activity in the rhizosphere, leading to enhanced rhizodegradation. The rhizosphere is the zone of soil around the root in which microbes are influenced by the root system forming a dynamic root-soil interface (Kuiper et al., 2004; Pilon-Smits, 2005; Barea et al., 2005). The use of microbial metabolic potential for eliminating soil pollutants provides a safe and economic alternative to other commonly used physico-chemical strategies (Vidali, 2001). Soil pollutants that are remediated by this method are generally organic compounds that cannot enter the plant because of their high hydrophobicity. Plants are generally not considered as the main mode of remediation in this technique. Plant-microbial interactions in the rhizosphere offer very useful means for remediating environments contaminated with recalcitrant organic compounds (Chaudhry et al., 2005). The root system of plants can help to spread bacteria through soil and help to penetrate otherwise impermeable soil layers. The plant creates a niche for rhizosphere microorganisms to do the degradation. Root exudates and root turnover can serve as substrates for microorganisms that perform pollutant degradation. Selection for organisms that may be useful in rhizoremediation has been attempted with good success. Studies of the most suitable plant species for rhizoremediation showed that various grass varieties and leguminous plants such as alfalfa are suitable (Kuiper et al. 2001; Qiu et al. 1994; Shann and Boyle 1994). This probably is due to their ability to harbor large numbers of bacteria on their highly branched root systems. When a site gets polluted, the composition of the indigenous microbial population in the soil and ground water will adapt to this new situation. Bacteria able to use the pollutant substrates as a nutrient source will be able to proliferate and may become dominant (Liu and Suflita 1993). The natural, non-engineered process of degradation of xenobiotics by the indigenous microbial population is referred to as natural attenuation, and is regarded as the simplest form of bioremediation. The Environmental Protection Agency (EPA,United States) defines natural attenuation, or intrinsic remediation, as a combination of degradation, dispersion, dilution, 
sorption, volatilization, and chemical and biochemical stabilization of contaminants. Bioaugmentation is a method to improve degradation and enhance the transformation rate of xenobiotics by the injection (seeding) of specific microbes, able to degrade the xenobiotics of interest. Many microbes are described to have the genetic tools to mineralize recalcitrant pollutants such as PAHs, chlorinated aliphatics and aromatics, nitroaromatics, and long-chain alkanes (Cerniglia 1993; Cerniglia and Heitkamp 1987; Grosser et al. 1991; Heidelberg et al. 2002; Kastner and Mahro 1996).In this review, some generally accepted rhizoremediations are described. The aim of present review is to provide improved understanding of mechanism of microbial interaction in rhizosphere, which will help to translate the results of simplified bench scale and pot experiments to the full complexity and heterogeneity of field experiments with predictable remedial success.

\section{Plants suitable for rhizoremediation}

The first studies toward degradation of compounds in the rhizosphere mainly focused on the degradation of herbicides and pesticides (Hoagland et al. 1994; Jacobsen 1997; Zablotowicz et al. 1994). These studies suggested that plants are protected against these compounds by the degrading bacteria. Research on phytoremediation, through trial and error, has focused on densely rooted, fast growing grasses and plants, such as Brassica sp., with fine root systems. Mulberry (Morus alba L.) and poplar (Populus deltoides) trees have been used successfully in the phytoremediation of chlorophenols and chlorinated solvents such as trichloroethylene (TCE) (Stomp et al. 1993).Various grass varieties and leguminous plants have shown to be suitable for rhizoremediation (Kuiper et al., 2001, 2004).

\section{Role of plants in rhizoremediation}

The mucigel secreted by root cells, lost root cap cells, the starvation of root cells, or the decay of complete roots provides nutrients in the rhizosphere (Kuiper et al., 2004; Lynch \& Whipps, 1990). In addition, plants release a variety of photosynthesis derived organic compounds (Pilon-Smits, 2005; Salt et al., 1998). These root exudates contain water soluble, insoluble, and volatile compounds including sugars, alcohols, amino acids, proteins, organic acids, nucleotides, flavonones, phenolic compounds and certain enzymes (Chaudhry et al., 2005; Pilon-Smits, 2005; Salt et al., 1998; Anderson et al., 1993). Plants may contribute to remediation in several ways, by reducing the leaching of contaminants, aerating soil, phytodegradation/transformation, phytovolatilization, evapotranspiration, and rhizoremediation (Amos \& Younger, 2003; Chang et al., 2005; Cunningham et al., 1995). The selection of bioremediation or phytoremediation for cleanup of a contaminated site may depend upon prevailing conditions that support the application of microbes, plants, and/or both.

\section{Factors affecting rhizoremediation:}

The differing physical, chemical, and biological properties of the root-associated soil, compared with those of the bulk soil, are responsible for changes in microbial diversity and for increased numbers and metabolic activities of microorganisms in the rhizosphere microenvironment, the phenomenon called the rhizosphere effect (Barea et al., 2005; Kuiper et al., 2004; Pilon-Smits, 2005; Salt et al., 1998).The effects of soil moisture, temperature, aeration, $\mathrm{pH}$, and organic matter content on the biodegradation of pesticides have been investigated in many studies (Bending et al., 2006; Charnay et al., 2005; Rasmussen et al., 2005).

The rate of exudation changes with the age of a plant, the availability of mineral nutrients and the presence of contaminants (Chaudhry et al., 2005). The nature and the quantity of root exudates, and the timing of exudation are crucial for a rhizoremediation process. The root exudates mediate acquisition of minerals by plants and stimulate microbial growth and activities in the rhizosphere in addition to changing some physicochemical conditions. Plants might respond to chemical stress in the soil by changing the composition of root exudates controlling, in turn, the metabolic activities of rhizosphere microorganisms (Chaudhry et al., 2005). Some organic compounds in root exudates may serve as carbon and nitrogen sources for the growth and long-term survival of microorganisms that are capable of degrading organic pollutants (Pilon-Smits, 2005; Salt et al., 1998; Anderson et al., 1993).

\section{Soil Conditions:}

The success of bioremediation depends on a number of soil physico-chemical factors such as moisture, redox conditions, temperature, $\mathrm{pH}$, organic matter, nutrients and nature, and amount of clay that affect microbial activity and chemical diffusion in soils. Schroll et al. (2006) quantified the effect of soil moisture on the aerobic microbial mineralization of selected pesticides (isoproturon, benzolin-ethyl, and glyphosphate) in different soils. They found a linear correlation $(p<0.0001)$ between increasing soil moisture (within a soil water potential range of -20 and $-0.015 \mathrm{MPa}$ ) and increased relative pesticide mineralization. 


\section{Temperature:}

Temperature and $\mathrm{pH}$ are the major factors affecting the biodegradation of pesticides in soil. Temperature not only affects the rates of biochemical reactions, as all microbial activities depend on thermodynamics, but also has a direct impact on cell physiology-altering proteins and cell membrane permeability (Alberty, 2006; Guillot et al., 2000; Mastronicolis et al., 1998).

pH:

The biodegradation of a compound is dependent on specific enzymes secreted by microorganisms. These enzymes are largely $\mathrm{pH}$-dependent and bacteria tend to have optimum $\mathrm{pH}$ between 6.5 and 7.5 , which equals their intracellular pH. A Pandoraea sp. isolated from an enrichment culture (Okeke et al., 2002) degraded $\mathrm{HCH}$ isomers over a $\mathrm{pH}$ range of 4 to 9 (Siddique et al., 2002), but the optimum pH for growth and biodegradation of $\alpha$ - and $\gamma$-isomers of HCH in soil slurries was 9. Singh et al. (2006) also reported the similar results while studying the biodegradation of organophosphate pesticides in soil. Degradation rate was slower in lower $\mathrm{pH}$ soils in comparison with neutral and alkaline soils.

\section{Soil organic matter:}

Soil organic matter also affects biodegradation of pesticides in soil by providing nutrients for cell growth and controlling pesticide movement by adsorption/desorption processes. Perrin-Ganier et al. (2001) monitored biodegradation of isoproturon (herbicide) by adding sewage sludge, nitrogen $(\mathrm{N})$, and phosphorus $(\mathrm{P})$ separately and observed that $\mathrm{N}$ and $\mathrm{P}$ had the greatest effect on isoproturon degradation.

\begin{tabular}{|c|c|c|}
\hline \multicolumn{3}{|c|}{$\begin{array}{l}\text { Recent Research Studies Implying Rhizoremediation } \\
\text { Plant species shown to facilitate microbial degradation }\end{array}$} \\
\hline $\begin{array}{l}\text { Plant } \\
\text { rhizosphere }\end{array}$ & Pollutant & Reference \\
\hline Sugarcane & $2,4-\mathrm{D}$ & Sandman and Loos, 1984 \\
\hline Rice & Benthiocarb & $\begin{array}{l}\text { Sato, } \\
1989\end{array}$ \\
\hline Corn & Atrazine & Seibert et al., 1981 \\
\hline Kochia & $\begin{array}{l}\text { Atrazine, metolachlor, } \\
\text { and trifluralin }\end{array}$ & Anderson et al.1994 \\
\hline Zinnia anguistifolia & Mefenoxam & Pai et al.(2001) \\
\hline $\begin{array}{l}\text { Rye } \\
\text { grass }\end{array}$ & Chlorpyrifos & Korade and Fulekar,2010 \\
\hline $\begin{array}{l}\text { Pennisetum } \\
\text { pedicellatum }\end{array}$ & $\begin{array}{l}\text { Chlorpyrifos } \\
\text { Cypermethrin } \\
\text { Fenvalerate } \\
\end{array}$ & Dubey and Fulekar, 2011a \\
\hline Rice (cv. Supriya) & Parathion & Reddy and Sethunathan 1983 \\
\hline $\begin{array}{l}\text { Mixture of grass, legume, herb } \\
\text { and pine }\end{array}$ & Trichloroethylene & Walton and Anderson 1990 \\
\hline Prairie grasses & $\begin{array}{l}\text { Polycyclic aromatic } \\
\text { hydrocarbons (PAHs) }\end{array}$ & Aprill and Sims 1990 \\
\hline Prairie grasses & $\begin{array}{l}\text { Polycyclic aromatic } \\
\text { hydrocarbons (PAHs) }\end{array}$ & Qiu et al. 1994 \\
\hline Grasses and alfalfa & $\begin{array}{l}\text { Pyrene, } \\
\text { anthracene,phenanthrene }\end{array}$ & Schwab et al. 1995 \\
\hline Sugar beet (cv. Rex) & $\begin{array}{l}\text { Polychlorinated biphenyls } \\
\text { (PCBs) }\end{array}$ & Brazil et al. 1995 \\
\hline Barley (Hordeum vulgare) & $2,4-\mathrm{D}$ & Jacobsen 1997 \\
\hline Alfalfa and alpine bluegrass & Hexadecane and PAHs & Nichols et al. 1997 \\
\hline Wheat (Triticum aestivum) & $2,4-\mathrm{D}$ & Kingsley et al. 1994 \\
\hline
\end{tabular}


Rhizoremediation: A Promising Rhizosphere Technology

\begin{tabular}{|l|l|l|}
\hline $\begin{array}{l}\text { Poplar (Populus deltoides } \\
\text { nigra) }\end{array}$ & 1,4-dioxane & Schnoor et al. 1998 \\
\hline Wheat & Trichloroethylene & Yee et al. 1998 \\
\hline $\begin{array}{l}\text { Oat, lupin, rape, dill, pepper, } \\
\text { radish, pine }\end{array}$ & Pyrene & Liste and Alexander 2000 \\
\hline $\begin{array}{l}\text { Reed (Phragmitis australies) } \\
\text { Abd El }\end{array}$ & Fixed nitrogen & Haleem et al. 2000 \\
\hline Poplar root extract & 1,4-dioxane & Kelley et al. 2001 \\
\hline Corn (Zea mays) & 3-methylbenzoate & Ronchel et al. 2001 \\
\hline Astragalus sinicus & Cd & Sriprang et al. 2002 \\
\hline Fern (Azolla pinnata & Diesel fuel & Cohen et al. 2002 \\
\hline
\end{tabular}

\section{Conclusion}

Rhizoremediation technology uses plant roots and associated microbial consortium to degrade environmental pollutants/toxins from soil with an aim of restoring area sites to a condition useable for intended purpose. Rhizoremediation takes advantage of plant roots natural symbiosis with mycorrhiza and root associated natural microbial flora for the enhanced degradation of pollutants in the rhizosphere. Although the studies described above represent only one pollutant and for one plant-bacterium combination, it is clear that similar microbe-plant combinations can be selected for other pollutants. Therefore, further studies of the selection of suitable rhizosphere bacteria or communities, able to sustain and proliferate on the root system of a plant which is suitable for rhizoremediation or phytoremediation, can yield useful novel (engineered) systems. These systems then can be an interesting tool to further improve and develop bioremediation into a widely accepted technique.

\section{Reference}

[1]. Abd El Haleem, D., von Wintzingerode, F., Moter, A., Moawad, H., and Gobel, U. B. 2000. Phylogenetic analysis of rhizosphereassociated beta-subclass proteobacterial ammonia oxidizers in a municipal waste water treatment plant based on rhizoremediation technology. Lett.Appl. Microbiol. 31:34-38.

[2]. Alberty, R.A. 2006 Biochemical reactions at specified temperature and various pHs. In Biochemical thermodynamics.

[3]. Amos, P.W., and Younger, P.L. 2003 Substrate characterisation for a subsurface reactive barrier to treat colliery spoil leachate. Water Res., 37, 108-120.

[4]. Anderson, T. A., Guthrie, E. A., and Walton, B. T. 1993. Bioremediation in the rhizosphere. Environ. Sci. Technol. 27:2630-2636.

[5]. Anderson J.A., Kruger E.R., Coats J.R. 1994 Enhanced degradation of a mixture of three herbicides in the rhizosphere of a herbicide tolerant plant. Chemosphere 28: 1551-1557

[6]. Aprill, W., and Sims, R. C. 1990. Evaluation of the use of prairie grasses for stimulating polycyclic aromatic hydrocarbon treatment in soil.Chemosphere 20:253-265.

[7]. Barea J.M., Pozo M.J., Azcón R. \& Azcón-Aguilar C. 2005 Microbial co-operation in the rhizosphere. J Exp Botany 56: 1761-1778.

[8]. Bending, G.D., Lincoln, S.D., and Edmondson, R.N. 2006 Spatial variation in the degradation rate of the pesticides isoproturon, azoxystrobin and diflufenican Bioremediation and Phytorem-ediation of Pesticides in soil and its relationship with chemical and microbial properties. Environ. Pollut., 139, 279-287.

[9]. Brazil, G. M., Kenefick, L., Callanan, M., Haro, A., de Lorenzo, V., Dowling, D. N., and O'Gara, F. 1995. Construction of a rhizosphere Pseudomonad with potential to degrade polychlorinated biphenyls and detection of bph gene expression in the rhizosphere. Appl. Environ.Microbiol. 61:1946-1952.

[10]. Cerniglia, C. E., and Heitkamp, M. A. 1987. Microbial degradation of polycyclic aromatic hydrocarbons (PAH) in the aquatic environment.Pages 41-68 in: Metabolism of Polycyclic Aromatic Hydrocarbons in the Aquatic Environment. U. Varanasi, ed. CRC Press, Inc., BocaRaton, FL, U.S.A.

[11]. Cerniglia, C. E. 1993. Biodegradation of polycyclic aromatic hydrocarbons.Curr. Opin. Biotechnol. 4:331-338.

[12]. Chang, S.W., Lee, S.J., and Je, C.H. 2005 Phytoremediation of atrazine by poplar trees: Toxicity, uptake, and transformation. J. Environ. Sci. Health, 40, 801-811.

[13]. Charnay, M., Tuis, S., Coquet, Y., and Barriuso, E. 2005 Spatial variability in 14Cherbicide degradation in surface and subsurface soils. Pest Manage. Sci., 61,845-855.

[14]. Chaudhry Q., Blom-Zandstra M., Gupta S. \& Joner E.J. 2005 Utilising the synergy between plants and rhizosphere microorganisms to enhance breakdown of organic pollutants in the environment. Environ Sci Pollut Res 12: 34-48.

[15]. Cohen, M. F., Williams, J., and Yamasaki, H. 2002. Biodegradation of diesel fuel by an Azolla-derived bacterial consortium. J. Environ. Sci. Health Part A Toxic-Hazard Subst. Environ. Eng. 37:1593- 1606.

[16]. Cunningham, S.D., Berti, W.R., and. Huang, J.W. 1995 Phytoremediation of contaminated soils. Trends Biotechnol., 13, 393-397.

[17]. Dubey, K.K., and Fulekar, M.H., 2011a Effect of pesticides on the Seed Germination of Cenchrus setigerus and Pennisetum pedicellatum as Monocropping and Co-cropping System: Implications for Rhizospheric Bioremediation. Romanian Biotechnological Letters Vol. 16, No. 1, 5909-19

[18]. Grosser, R. J., Warshawsky, D., and Vestal, J. R. 1991. Indigenous and enhanced mineralization of pyrene, benzo(a)pyrene, and carbazole in soils. Appl. Environ. Microbiol. 57:3462-3469.

[19]. Guillot, A., Obis, D., and Mistou, M.Y. 2000 Fatty acid membrane composition and activation of glycine-betaine transport in Lactococcus lactis subjected to osmotic stress. Int. J. Food Microbiol., 55, 47-51.

[20]. Heidelberg, J. F., Paulsen, I. T., Nelson, K. E., Gaidos, E. J., Nelson, W. C., Read, T. D., and Eisen, J. A. 2002. Genome sequence of the dissimilatory metal ion-reducing bacterium Shewanella oneidensis. Nature Biotechnol. 1:1-6. 
[21]. Hoagland, R. E., Zablotowicz, R. M., and Locke, M. A. 1994. Propanil metabolism by rhizosphere microflora. Pages 160-183 in: Bioremediation through Rhizosphere Technology. T. A. Anderson and J. R. Coats, eds. American Chemical Society, Washington, D.C.

[22]. Jacobsen, C. S. 1997. Plant protection and rhizosphere colonization of barley by seed inoculated herbicide degrading Burkholderia (Pseudomonas) cepacia DBO1(pRO101) in 2,4-D contaminated soil. Plant Soil 189:139-144.

[23]. Kamaludeen SPBK, Arunkumar KR, Avudainayagam S, Ramasamy K, 2003. Bioremediation of chromium contaminated environments. Ind. J. Exp Bio., 41: pp 972985.

[24]. Kastner, M., and Mahro, B. 1996. Microbial degradation of polycyclic aromatic hydrocarbons in soils affected by the organic matrix of compost. Appl. Microbiol. Biotechnol. 44:668-675.

[25]. Kelley, S. L., Aitchison, E. W., Deshpande, M., Schnoor, J. L., and Alvarez, P. J. 2001. Biodegradation of 1,4-dioxane in planted and unplanted soil: effect of bioaugmentation with Amycolata sp. CB1190. Water Res. 35:3791-3800.

[26]. Kingsley, M. T., Fredrickson, J. K., Metting, F. B., and Seidler, R. J. 1994. Environmental restoration using plant-microbe bioaugmentation. Pages 287-292 in: Bioremediation of Chlorinated and Polyaromatic Hydrocarbon Compounds. R. E. Hinchee, A. Leeson, L. Semprini, and S. K. Ong, eds. Lewis Publishers, Boca Raton, FL, U.S.A.

[27]. Korade, D.L., Fulekar M.H., 2009. Rhizoremediation of Chlorpyrifos in mycorrhizospheric soil using rye grass. Journal of Hazardous Materials, 172, 2-3, (30)1344-1350

[28]. Kuiper, I., Bloemberg, G. V., and Lugtenberg, B. J. J. 2001. Selection of a plant-bacterium pair as a novel tool for rhizostimulation of polycyclic aromatic hydrocarbon-degrading bacteria. Mol. Plant-Microbe Interact. 14:1197-1205.

[29]. Kuiper, I., Lagendijk, E.L., Bloemberg, G.V. \& Lugtenberg, B.J.J., 2004. Rhizoremediation: A beneficial plant microbe interaction. Mol Plant Microbe Interact, 17: 6-15.

[30]. Liste, H.-H., and Alexander, M. 2000. Plant-promoted pyrene degradation in soil. Chemosphere 40:7-10.

[31]. Liu, S., and Suflita, J. M. 1993. Ecology and evolution of microbial populations for bioremediation. Tibtech 11:344-352.

[32]. Lynch, J. M. and J. M. Whipps. 1990. Substrate flow in the rhizosphere. Plant Soil 129:1-10.

[33]. Mastronicolis, S.K., German, J.B., Megoulas, N., Petrou, E., Foka, P., and Smith, G.M. 1998. Influence of cold shock on the fattyacid composition of different lipid classes of the food-borne pathogen Listeria monocytogenes. Food Microbiol., 15,299-306

[34]. Nichols, T. D., Wolf, D. C., Rogers, H. B., Beyrouty, C. A., and Reynolds, C. M. 1997. Rhizosphere microbial populations in contaminated soils. Water Air Soil Pollut. 95:165-178.

[35]. Okeke, B.C., Siddique, T., Arbestain, M.C., and Frankenberger, W.T., 2002. Biodegradation of $\gamma$-hexachlorocyclohexane and $\alpha-$ hexachlorocyclohexane in water and soil slurry by Pandoraea sp. J. Agric. Food Chem., 50, 2548-2555.

[36]. Pai, S.G., Riley, M.B., Camper, N.D., 2001. Microbial degradation of mefenoxam in rhizosphere of zinnia anguistifolia. Chemosphere, 577-582.

[37]. Pilon-Smits E., 2005 Phytoremediation. Annu Rev Plant Biol 56: 15-39.

[38]. Qiu, X., Shah, S. I., Kendall, E. W., Sorensen, D. L., Sims, R. C., and Engelke, M. C. 1994. Grass-enhanced bioremediation for clay soils contaminated with polynuclear aromatic hydrocarbons. Pages 142 - 157 in: Bioremediation Through Rhizosphere Technology. T. A.

[39]. Anderson and J. R. Coats, eds. American Chemical Society, Washington, D.C.

[40]. Rasmussen, G. \& Olsen, R.A., 2005 Sorption and biological removal of creosote-contaminants from groundwater in soil/sand vegetated with orchard grass (Dactylis glomerata) Adv Environ Res 8: 313-327.

[41]. Reddy, B. R., and Sethunathan, N. 1983. Mineralization of parathion in the rice rhizosphere. Appl. Environ. Microbiol. 45:826-829.

[42]. Ronchel, M. C., and Ramos, J. L. 2001. Dual system to reinforce biological containment of recombinant bacteria designed for rhizoremediation.Appl. Environ. Microbiol. 67:2649-2656.

[43]. Salt, D.E., Smith, R.D., \& Raskin, I., 1998 Phytoremediation. Annu Rev Plant Physiol 49: 643-668.

[44]. Sandman, E., Loos, M.A., 1984 Enumeration of 2, 4-D degrading microorganisms in soils and crop plant rhizospheres using indicator media: high populations associated with sugarcane (Saccharum officinarum), Chemosphere 13, $1073-1084$.

[45]. Sato, K. 1989. In Interrelationships between Microorganisms and Plants in Soil; Vancura, V., Kunc, F., Eds.; Elsevier: New York; pp. 335-42

[46]. Schnoor, J. L., Aitchison, E. W., Kelley, S. L., and Alvarez, P. J. J. 1998. Phytoremediation and bioaugmentation of 1,4-dioxane. Pages 87-91. Abstr. Adv. Biol. Syst. Rem. Conf. March 1998.

[47]. Schroll, R., Becher, H.H., Dorfler, U., Gayler, S., Grundmann, S., Hartmann, H.P., and Ruoss, J. 2006. Quantifying the effect of soil moisture on the aerobic microbial mineralization of selected pesticides in different soils. Environ. Sci. Technol., 40, 3305-3312

[48]. Schwab, A. P., and Banks, M. K. 1994. Biologically mediated dissipation of polyaromatic hydrocarbons in the root zone. Pages 132-141 in: Bioremediation Through Rhizosphere Technology. T. A.Anderson and J. R. Coats, eds. American Chemical Society, Washington, DC.

[49]. Seibert, K., Fuehr, F., Cheng, H. H., 1981. In Theory and Practical Use of Soil-Applied Herbicides Symposium; European Weed Resource Society: Paris, pp. 137-46

[50]. Shann, J. R., and Boyle, J. J. 1994. Influence of plant species on in situ rhizosphere degradation. Pages $70-81$ in: Bioremediation Through Rhizosphere Technology. T. A. Anderson and J. R. Coats, eds. American Chemical Society, Washington, DC.

[51]. Siddique, T., Okeke B.C., Arshad, M., and Frankenberger, W.T., Jr. 2002. Temperature and pH effects on biodegradation of hexachlorocyclohexane isomers in water and soil slurry. J. Agric. Food Chem., 50, 5070-5076.

[52]. Singh, B.K., Walker, A., and Wright, D.J. 2006. Bioremedial potential of fenamiphos and chlorpyrifos degrading isolates: Influence of different environmental conditions. Soil Biol. Biochem., 38, 2682-2693.

[53]. Sriprang, R., Hayashi, M., Yamashita, M., Ono, H., Saeki, K., and Murooka, Y. 2002. A novel bioremediation system for heavy metals using the symbiosis between leguminous plant and genetically engineered rhizobia. J. Biotechnol. 99:279-293.

[54]. Stomp A.M., Han K.H., Wilbert S., Gordon M.P. \& Cunningham S.D. 1994. Genetic strategies for enhancing phytoremediation. Ann NY Acad Sci 721: 481-492.

[55]. Vidali M. 2001. Bioremediation. An overview. Pure Appl Chem. 73:1163-72.

[56]. Walton, B. T., and Anderson, T. A. 1990. Microbial degradation of trichloroethylene in the rhizosphere: Potential application to biological remediation of waste sites. Appl. Environ. Microbiol. 56:1012-1016.

[57]. Yee, D. C., Maynard, J. A., and Wood, T. K. 1998. Rhizoremediation of trichloroethylene by a recombinant, root-colonizing Pseudomonas fluorescens strain expressing toluene ortho- monooxygenase constitutively. Appl. Environ. Microbiol. 64:112-118.

[58]. Zablotowicz, R. M., Hoagland, R. E., and Locke, M. A. 1994. Glutathione S-transferase activity in rhizosphere bacteria and the potential for herbicide detoxification. Pages 184-198 in: Bioremediation Through Rhizosphere Technology. T. A. Anderson and J. R. Coats, eds. American Chemical Society, Washington, DC. 